\title{
微膨胀混凝土后浇带防裂技术在水工结构中的应用浅议
}

何艳

汉中市石门水库管理局

DOI:10.32629/hwr.v4i5.3029

[摘 要] 随着社会不断的向着现代化的方向发展,越来越多的超长以及双向的超长建筑结构应用在实际的施工过程中。建筑结构施工中应用后 浇带技术具有重要的作用。本文针对微膨胀混凝土后浇带防裂技术在水工结构中的应用进行分析,对于保障水工建筑工程的施工起到了非常重 要的作用。

[关键词] 微膨胀混凝土; 后浇带防裂技术; 水工结构；应用

\section{1 简述微膨胀混凝土}

对于微膨胀混凝土而言, 本质是将一定量的膨胀剂添加到混凝土当中, 使混凝土在水化期间依靠其产生的化学反应而发生一定的膨胀, 从而补偿 混凝土的收缩, 以达到减少混凝土干缩裂缝的目的, 从而能够让抗裂性能 及其抗渗性进行提升, 从而能够广泛应用到地下防水工程, 屋面防水工程, 回填通塞及其基础后浇带 (宽缝) 等部位的作业。

\section{2 水工建筑中混凝土结构的防裂特点}

水工混凝土结构的一个非常明显的特点就是对防裂防渗性能的要求 非常高, 而水工结构中的混凝土通常都是大体积混凝土, 因此, 为了防止混 凝土温度应力裂缝以及控制混凝土的绝热升温成为水工建筑成败与否的 关键。微膨胀混凝土后浇带防裂技术在水工建筑工程中有效降低混凝土结 构发生施工温度裂缝的一种有效方式, 在民用建筑和工业建筑施工过程中 的应用已经非常广泛了, 这一种混凝土防裂技术在水工结构工程中也同样 适用, 通常情况下会和其他防裂技术进行有效结合构成水工混凝土结构的 整体的防裂手段。

有这样的一个渠道维修项目, 渠坡混凝土面板形成贯穿性裂缝, 局部 明显渗漏, 对渠道运行安全造成极大的威胁。全部破除重建造价高, 而且存 在这一问题的渠坡不在少数。技术人员提出延裂缝剔除原面板 $5-10 \mathrm{~cm}$ 宽槽, 换微膨胀混凝土填筑的维修方法, 并在一段问题渠坡上进行了试验。面板 修补完成通水运行后, 新填混凝土与原面板结合紧密, 除新旧混凝土表面 颜色不一样外, 表面平整。渠道原有渗水没有了, 基本解决了裂缝问题。这 一方式在其他类似面板裂缝处理问题上得到了普遍应用。

\section{3 钢筋的处理}

为避免因为在支设模板以及浇筑混凝土的时候出现钢筋偏移的现象, 导致对整个建筑结构的性能造成不良影响, 在实际的施工操作过程中, 必 须严格按照设计图纸, 对钢筋进行绑扎和固定; 对于断开的钢筋, 首先标记 出位置, 然后委派专人进行维护, 调整接头所处的位置。绑扎钢筋时, 应避 免漏绑、错绑的情况, 还应该设置合理的保护层厚度; 钢筋焊接前, 应该检 查后浇带施工现状, 确保满足施工要求。通过常规施工措施完成配筋工作, 确保其能够顺利穿过后浇带, 并且提高施工效率。

\section{4 后浇带内混凝土的级配及浇筑方法}

混凝土施工前, 要对有关材料进行试验检测, 主要包括水泥、砂、石, 提出合理设计混凝土的配合比。以水泥为例, 检测项目有细度、强度、凝 结时间、体积安定性、标准稠度用水量等, 检测不合格不能进场使用。在 进行机械振捣过程中要遵照相关的秩序, 为防止引起原混凝土发生振裂, 在离缝边 $90 \mathrm{~mm}$ 的地方要停止继续振捣, 再通过人工捣实措施促使施工缝接 缝位置的结合更加有效。

\section{5 后浇带内混凝土的浇筑方法及养护方法}

在摚拌混凝土的过程中, 一定要严格控制材料的使用量, 提高混凝土 搅拌的均匀程度, 避免膨胀出现程度不一的现象, 给混凝土的质量以及性 能等造成不良的影响。在进行混凝土的浇筑工作时还应该严格的按照工程 施工的要求, 对养护空间进行合理的设计和安排, 确保后浇带部位混凝土 的强度能够达到施工要求。通常情况下, 在掺入了微膨胀剂之后, 可以适当 的延长混凝土的摚拌时间。

为了提高混凝土的使用性能, 延长混凝土的使用寿命, 在完成混凝土 的浇筑工作之后, 一定要做好后期的维护工作。通常在混凝土表面铺设覆 盖层, 尤其注意保护边角部位, 避免破损、脱落; 将养护时间控制在7天以 上, 确保混凝土表面处于湿润状态, 防止出现裂纹、裂缝; 在后浇带混凝土 的强度达到了 $100 \%$ 之后才可以将模板拆除; 整个养护作业期间, 禁止行人 或车辆在结构上走行, 防止结构变形, 或造成不均匀沉降。

\section{6 模板技术}

6. 1混凝土浇筑后的区域 (跨区) 中的模板支撑应独立于相邻零件两侧 的模板支撑系统。并且零件应根据施工图进行构造, 不得在两侧与相邻的 模板支撑系统连接, 以免支撑系统的应力变化对拆卸的零件产生影响, 整 个支撑系统是路堤两个相邻侧面。

6. 2 回填土对底部支撑强度进行受力时, 由于长期支持系统的位置, 在下雨和下雪的天气很容易遇到施工过程和周围环境, 因此必须对回填 进行压实, 填充物应分层, 并且填充物的压实测试应确保填充物的压实 位置。根据回填的承载能力, 支撑板的强度以及支撑杆在该区域底部的 设置。背板应跨 2 至 3 个垂直杆, 以提高轴承表面和垂直线的承载能力, 或 加强基础部分。

\section{7 结语}

综上所述, 在建筑过程中通过对建筑主体进行后浇带设置的方式, 可 以在最大程度上实现建筑物的大空间结构, 并且可以在最大程度上降低建 筑主体出现不良伸缩以及沉降等方面的问题, 在实际施工过程中一定要严 格按照设计图纸上的相关要求进行科学合理的施工, 以这样的方式来确保 建筑工程施工的整体质量。因此, 微膨胀混凝土后浇带防裂技术在我国建 筑水工结构工程中的成功应用, 为我国以后的建筑物的大空间结构建设技 术进行实际应用和不断完善, 以便在类似工程中更为成功的进行应用。

[参考文献]

[1]梁剑.微膨胀混凝土后浇带防裂技术在水工结构中的应用 [J].价值 工程,2019,38(36):243-244.

[2]赵文超. 微膨胀混凝土后浇带防裂技术在水工结构中的应用研究 [J].科技资讯, 2013,(35):44-45.

[3]张修童.微膨胀混凝土后浇带防裂技术在水工结构中的应用 [J].山 东工业技术,2019,(01):102. 